\title{
HIV-TB the deadly duo, the biggest health challenge in Fiji
}

\author{
Santhakumari Muller ${ }^{*}$, Vinod Narayan Sami \\ From First International Science Symposium on HIV and Infectious Diseases (HIV SCIENCE 2012) \\ Chennai, India. 20-22 January 2012
}

\section{Background}

Tuberculosis is a common opportunistic infection and HIV patients with latent TB infection are at risk of reactivation and those with recently acquired infection are at high risk of progressive primary TB. Approximately 1000 people in the western pacific region die from the disease every day. The threat of increasing HIV rates fuelling the TB epidemic has become an important massive challenge in Fiji to the control of $\mathrm{TB}$ at all levels. Hence this study was to evaluate the rate of TB co infection among HIV patients in Fiji.

\section{Methods}

This study involved the retrospective descriptive analysis of the data available in the PJ Twomey Hospital, Suva, Fiji. All registered cases of HIV and HIV-TB has been included in the study.

\section{Results}

By 2010, Fiji has 191 registered cases of tuberculosis and 393 HIV positive. The \% of TB patients with known HIV status is 100 because of the recent Fiji HIV/TB surveillance policy which recommends that HIV testing is mandatory in all newly diagnosed cases of $\mathrm{TB}$ for all health care settings. Fiji has reported $2 \%$ of new TB patients every year which are also HIV positive and the mortality rate of HIV/TB patients is very high (80\%).

\section{Conclusion}

The HIV positive co-infected with TB have developed active TB than patients who are HIV negative. Hence the TB/HIV co-infected were started TB therapy prior to ARVs. TB treatment reduces the burden of HIV in people living with TB.

* Correspondence: Santha.Muller@fnu.ac.fj

Department of Health Sciences, College of Medicine, Nursing and Health Sciences, Fiji National University, Suva, Fiji
Published: 4 May 2012

doi:10.1186/1471-2334-12-S1-O22

Cite this article as: Muller and Sami: HIV-TB the deadly duo, the biggest health challenge in Fiji. BMC Infectious Diseases 2012 12(Suppl 1):O22.
Submit your next manuscript to BioMed Central and take full advantage of:

- Convenient online submission

- Thorough peer review

- No space constraints or color figure charges

- Immediate publication on acceptance

- Inclusion in PubMed, CAS, Scopus and Google Scholar

- Research which is freely available for redistribution

\section{() Biomed Central}

C Biomed Central

(c) 2012 Muller and Sami; licensee BioMed Central Ltd. This is an Open Access article distributed under the terms of the Creative Commons Attribution License (http://creativecommons.org/licenses/by/2.0), which permits unrestricted use, distribution, and reproduction in any medium, provided the original work is properly cited. 